\title{
The engineers of change
}

\author{
Who are the super-entrepreneurs?
}

ntrepreneurs are the engineers of biotechnology. They venture where no others have gone, risk their reputations and other people's money, and push out the boundaries of what can be known and what can bedone. Without them, there would be no fragile corporate vessels setting sail, no new courses charted, no innovation. Without entrepreneurs, biotechnology would become mere scientific endeavor and routine money-making.

In the following article, I focus on the rare individuals who do not merely touch the world with their enterprise, but who set out to change the world to increase the chances of their enterprise succeeding. Frequently, their success has been mixed.

Entrepreneurialism is as much about having the vision to see what is necessary as it is about reaping rewards and accolades, even though it is the achievers who are most widely remembered. Although their achievements may be commonplace and mundane, entrepreneurs change the circumstances in which all companies operate, and facilitate the achievements of others.

\section{Steve Holtzman}

\section{Holtzman is one of the most creative biotechnology business innovators the sector has seen in the past ten years.}

Steve Holtzman was the founding executive director of the Ohio Edison Program, the first US state government program that aimed to drive economic development by funding young technology-based ventures and technology transfer from academia to industry. From 1986 to 1994, he was a founder, and the first employee, of transgenic animal specialist DNX (Princeton, $\mathrm{NJ}$ ), eventually becoming president of DNX Bio-Therapeutics, DNX's wholly owned biotechnology subsidiary (now

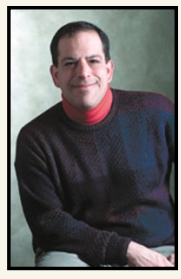

Citation: For serial innovation in constructing and executing novel business models, and for showing how to win the race against technical commoditization.

Education: BA, philosophy, Michigan

State University, 1976; BPh, philosophy, Oxford University, 1979 (Rhodes scholar) Age: 48

Nationality: American

Years in biotech: 16

Current post: Founder and CEO of Infinity Pharmaceuticals (Boston, MA)
Nextran, a subsidiary of Baxter

Healthcare).

Holtzman rose to prominence as chief business officer of one of the fastestgrowing biotechnology companies-in employee number and market capitalization- of the 1990s, M illennium

Pharmaceuticals (Cambridge, M A). In retrospect at least, the key stages of Millennium's transition from a 50-person genomics enterprise in 1994 to a 1,400-person integrated biopharmaceutical company in June 2001, when Holtzman left, appear to follow a beautiful logic. Steve Holtzman was instrumental in most of them, at each stage using M illennium's existing assets as a lever to build not only new businesses but also new assets.

In the first phase (1994-1996),

Holtzman was the architect of several of Millennium's gene-discovery deals: with Roche (Basel, Switzerland) in obesity and diabetes; with Eli Lilly (Indianapolis, IN) in atherosclerosis; with Astra (Stockholm, Sweden) in inflammatory respiratory diseases; and with American $\mathrm{H}$ ome Products ( $M$ adison, $\mathrm{NJ}$ ) in central nervous system indications. The deals brought the company crucial associations with big pharma and funding for research and development, but the Lilly deal also gave M illennium
John Hodgson is N ature Biotechnology's editor-at-large. 


\section{In his own words...}

Self-image: "I am not a deal guy; I am shy and hate to sell. I am an educator and a builder who believes in the power of the modern medical and life sciences to make a difference to the quality of life. As I am not capable, myself, of creating new medicines, my job is to create and enable a work environment and social organization that can unleash the innovative potential of great people to make that difference."

Moment of greatest clarity: "No single moment of clarity: it has been more like the way the light emerges at dawn to illuminate the landscape; the prominence of different features becomes apparent as the intensity and angle of the light alters."

Advice to entrepreneurs: "Focus on how to enable your coworkers to make important new medicines."

Advice to government: "Accept and acknowledge that higher pharmaceutical pricing in the US is a means by which this nation subsidizes medical research for the entire world ... and that this is a good thing."

Most common cause of life science failure: "Failure to integrate one's thinking technology and science. Organizational design and development, financing and alliances must form a seamless cloth from which you weave a great company."

Worst business habit (self or others): "Needing, instead of giving, credit."

access to high-throughput screening technologies and certain combinatorial chemistry libraries of Lilly's recently acquired subsidiary Sphinx Pharmaceuticals (Research Triangle Park, NC), and the American Home Products deal gave Millennium access to the pharmaceutical company's compounds for M illennium's proprietary drug discovery efforts.

In a later phase of growth (1997-1999), Holtzman and his team established a series of subsidiary ventures with multinational companies, including M illennium Biotherapeutics (1997) with Eli Lilly, for novel therapeutic proteins; Cereon Genomics (1997) with M onsanto (St. Louis, M O), for plant genomics; and $\mathrm{M}$ illennium Predictive M edicine (1999) with Becton Dickinson, in cancer diagnostics.

Then came the really big deals. Leveraging the company's achievements in efficient gene identification and gene association, Holtzman and M illennium's management hooked Bayer into a drug target-identification deal in September 1998 with a then-record headline value of $\$ 465$ million and upfront payments in excess of $\$ 130$ million. And on the back of its 1999 stock-swap acquisition of LeukoSite, Millennium established a clear franchise in oncology and inflammation that would lead to parity dealings with the pharmaceutical big boys. By 2000 , just seven years after its founding and four years after its initial public offering, Millennium was armed by $\mathrm{H}$ oltzman and his colleagues with sufficient near-market compounds, tested technology, and cash to enablethe company to enter groundbreaking alliances with Aventis in inflammation (potentially worth $\$ 450$ million) and Abbott Laboratories in metabolic diseases (valued at $\$ 250$ million). M illennium is now a junior partner to no one: the latter

\section{Philippe Pouletty}

deals were 50:50 development collaborations that gave it significant ownership and decision-making rights through the commercial process.

Holtzman and his colleagues have demonstrated that it is not only possible but perhaps also essential for a biotechnology company to expand its sphere of influence rapidly. The shape of the business and its immediate ambitions must change so that expectations continue to run ahead of achievements, and so that the specter of commoditization is never allowed to underminea company's value. Any number of companies can attest to the difficulty of growing real business from a genomic concept, and it is testimony to Holtzman and his team that M illennium has defied pigeonholing almost from the outset. Holtzman is a classical "intrapreneur," innovating many times within the confines of a single corporation. His "innovations," however, have influenced business practice much more broadly.

\section{Throughout his entrepreneurial career, Pouletty has demonstrated creativity and flexibility to overcome conditions that discourage new ventures.}

When Philippe Pouletty founded hisfirst company, Clonatec (Paris), in 1984, and his second, SangStat (Fremont, CA), in 1988, the environment for the growth of biotechnology businesses in France hardly recognized the needs of innovators. French academics, for instance, were prevented from holding stakes in commercial enterprises with which they were associated. Some small tax concessions persuaded domestic venture capitalists to invest in domestic biotechnology startups, but there was no recognition that biotechnology's capital needs extended beyond the venture phase. The government's idea of encouraging innovation was to establish a $\$ 150$ million program (BioAvenir), $60 \%$ of which was funded by the taxpayer, through which one largecompany, Rhône-Poulenc (RP; Paris), chose which projects from the French research centers should receive devel opment funds.

Few French biotechnology companies emerged. Of those that did, many simply

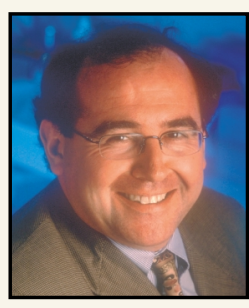

Citation: For channeling the protectionist tendencies of French governments toward the investment of significant public capital to support biotechnology.

Education: Immunology laureate, Institut Pasteur, 1983; MD, University of Paris VI, 1985; postdoctoral work, Stanford University, Department of Medical Microbiology and Immunology, 1986-1988 Age: 43

Nationality: French

Years in biotech: 17

Current posts: Board member, Conjuchem (Montreal, QC, Canada) and Innate-Pharma (Marseille, France); chairman, SangStat (Fremont, CA) and DrugAbuse Sciences (Paris); president, France Biotech (industry association); directeur général, Truffle Venture (Paris); president, Objectif 2010 (entrepreneurs' think tank) 


\section{In his own words...}

Self-image: "Look forward and do not easily give up."

Moment of greatest clarity: "Knowing that my children are far more important than my business achievements.'

Advice to entrepreneurs: "Look forward and never give up."

Advice to government: "Look forward and give up control ... to us."

Most common cause of life science failure: "Looking forward a little too far ahead."

Worst business habit (others): "Wasting your time and others' on insignificant issues when you could use it on big issues."

faded away again from cash starvation or ended up scratching out a meager living as service providers. Pouletty responded by establishing a presence for SangStat in the United States, enabling it to access US financial markets. SangStat went public on the Nasdaq in December 1993, raising $\$ 11.1$ million. Today, this seems like a glaringly obvious move to have made, but at the time SangStat was the first significant European, non-UK-based biotech to go public in the United States.

After founding Conjuchem (M ontreal, QC), which went public in Canada in 2000, Pouletty's next commercial preoccupation was D rugAbuse Sciences, a company, like SangStat, with operations on both sides of the Atlantic, in Hayward, California and in Paris. DrugAbuse is focused on developing products to counter cocaine overdoses and to help drug and alcohol abusers kick their habits. Uncharacteristically for the industry, the company could have had a product on the market before it went public. The company filed for a $\$ 40$ million public offering in February 2000, but the souring of the market and subsequent withdrawal of the offering in October 2000 meant that DrugAbuse had to return to privateinvestors for funding, raising $\$ 24$ million in April 2001. Pouletty recently cofounded TruffleVenture (Paris) to spin out products and technologies from large drug companies.

In Europe, where countries are small, the biotechnology industry young, and the basic business infrastructure for bioentrepre neurialism deficient, a single individual can make major changes to the status quo. Right now, in France, that individual is Pouletty. Hehas leveraged the high regard in which he is held, as a result of his earlier entrepreneurial endeavors, to extract government support for the wider French biotechnology enterprise. The French government continues to regard protectionist support for its established industrial bastions rather than encouraging entrepreneurial activity. However, through the think tank Objectif 2010, founded in 1998, and the industry lobby group of which hehas been president since 2001, FranceBiotech (Paris), Pouletty has convinced the government to back "Plan Biotech 2002."

Plan Biotech 2002 is a soft-money scheme, largely conceived by Pouletty, that aims to extract from government around $€ 150$ million in new financing: $€ 60$ million in the form of seed capital for new startups and $€ 90$ million as bank loan guarantees. The plan is that these guarantees will release around $€ 450$ million from French banks to allow French biotechnology companies to acquire foreign biotech companies and R\&D investments. Pouletty envisages that the current depressed markets could allow French companies, each backed by a loan of around $€ 50$ million, to acquire a number of US, German, and UK companies with low valuations. France Biotech and Pouletty have unashamedly been playing to the chauvinistic streak in French government thinking: the argument is that by implementing the plan, and by changing tax laws and doubling France's public $R \& D$ budget for biotechnology in each of the next five years, France could take the lead as a creator of European biotechnology businesses by 2007.

The run up to the presidential election in France provides Pouletty with the opportunity to push for this five-year plan: the two main candidates- especially current president Jacques Chirac - have al ready publicly endorsed several of hiskey proposals. Time will tell (after the election) whether these will betranslated into law and concrete action. Pouletty intends to remind the winner of those pre-election promises.

\section{Keith McCullagh}

\section{Despite a well-publicized failure at British Biotech, McCullagh remains one of the pioneers of UK biotechnology.}

Keith McCullagh worked his way through the pharmaceutical industry during the 1970 s and 1980s, holding a variety of senior $R \& D$, operations management, and advisory roles. He was research director at G.D. Searle (St. Louis, M O), a company that provided senior management and researchersfor sev-

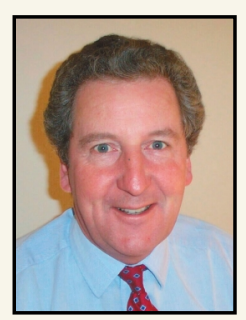

Citation: For prizing open Europe's public finance markets to your life science companies. Education: BVSc, University of Bristol, 1966; PhD, University of Cambridge, 1969

Age: 58

Nationality: British

Years in biotech: 17

Current posts: Chairman, OnMedica Group (Amersham, UK) and Pharmacy2U; director, MVM Ltd (UK Medical Research Council's venture capital subsidiary) eral of the United Kingdom's earliest biotechnology companies. As Searle's presence shrank in the UK, M cCullagh left the company in 1986 to found British Biotech (Oxford), becoming its chi ef executive officer. Ten years ago, biotechnology in the UK was a shadow of its current self. Yes, there were both a significant body of biological science and an effort by several companies to exploit that science, but no one had been able to unlock the huge coffers of theUK's considerable financial establishment. London was, and still is, Europe's largest financial market, but the rules of the London Stock Exchange (LSE) meant that only companies with significant revenues, profits, or trading histories could become public companies. Consequently, UK biotechnology companies grew slowly, and venture capital groups grew impatient and niggardly. Without the frisson of financial gain, the froth was going out of the sector, and as an enterprise, UK biotechnology was in danger of becoming un-enticing.

McCullagh, as chairman of the Biolndustry Association (London), a UK lobby group, together with British Biotech chairman Brian Richards, its financial 


\section{In his own words...}

Self image: "I regard myself as thoughtful, creative, diligent, of high integrity, rational and a leader. I am determined because I want to change the world for the better."

Moments of greatest clarity: "When Searle was sold in 1986 to Monsanto, who then decided to close down the European R\&D operations, I knew instantly that they had ignored one of the finest teams of pharma research scientists in the UK and that there was an opportunity to establish a new world-class bioscience research company .... The rest, as they say, is history."

"In early 1998, when I opened the letter from the European Medicines Evaluation Agency to learn that they had rejected British Biotech's NDA [new drug application] for the company's first product. I knew we had failed in my goal of building a new independent international pharmaceutical company. We announced it the next day .... The rest, as they say, is history."

Advice to entrepreneurs: "Focus on a single area of bioscience where you have the chance to become a world leader, hire the best people you can get, focus on unique proprietary opportunities, and communicate your strategy constantly-internally and externally."

Advice to government: "Invest heavily in education and science, match private investment funds in bioscience R\&D, support strong patent law, and abolish capital gains tax."

Most common cause of life science failure: "Inadequate finance for a high-quality operation; uncompetitive science; regulatory failure of 'breakthrough' product because of undemonstrated efficiency (often due to poor clinical design or development strategy); internal conflicts; poor leadership."

Worst business habit (self or others): "Following fads set by analysts and other commentators. Leaders should shape opinion and change ideas, not adopt received views uncritically."

director James Noble, and like-minded people such as Paul Haycock (then the CEO of Cambridge-based Cantab), lobbied the LSE in 1991. They wanted the LSE to change its listing rules to encompass firms that had no record of revenues, but had compounds that had not moved into clinical trials with patients and had an experienced management team. M cCullagh and colleagues persisted in their quest, and in 1992-1993 the LSE came up with its "Chapter 20" listing rules that enabled young high-tech companies to float.

Regardless of the fact that the new LSE description of a "listable" company was a cozy fit for British Biotech, other UK companies could also now raise money through Europe's premier capital market. British Biotech did so, as did Cantab, Chiroscience (Cambridge), Celsis (Cambridge), Biocompatibles (Uxbridge), Scotia (London), and many others. And, when looked at in the round, it probably did not matter either that, in theend, many of these companies, including British Biotech, proved not to be the successes investors had hoped for. Indirectly at least, the current crop of leading UK biotechnology companies have Keith M cCullagh to thank for being able sustain their pre-profitability existence. UK companies such as Celltech (Slough), Powderject Pharmaceuticals (Oxford), Oxford GlycoSciences (Oxford), Acambis (Cambridge), and Cambridge Antibody Technology (Cambridge) have grown, and can continue to grow, because they can access significant local public capital. Furthermore, venture capital groups

\section{J on Saxe} most successful serial entrepreneurs.
Jon Saxe ended a 29-year career at H offmannLa Roche (Nutley, N J) as head of licensing and corporate development to lead Synergen

(Boulder, CO) toward what was hoped to be could view UK biotechnology as an area of lowered risk, now that-at least in principle-an exit route through local flotation was possible. And what had happened in the UK would be repeated elsewhere in Europe as "new market" bourses opened to serve venture-backed companies.

M cCullagh also chaired the Group on the Financing of High Technology Businesses that advised the UK government's treasury department. The treasury has now implemented most of the group's recommendations- capital gain tax reform, $R \& D$ tax credits, and changes to the minimum funding requirements for pension fund asset managers.

What subsequently happened to M cCullagh and to British Biotech certainly served to erode M cCullagh's reputation (see Nat. Biotechnol. 16, 503, 1998; Nat.

Biotechnol. 16, 609, 1998). But while he may be principally responsible for the hundreds of millions chopped off British Biotech's valuation - at its vastly inflated peak, the company's market value was around $\$ 2$ billion compared with less than $\$ 150$ million today- he can also chalk up a significant proportion of the $\$ 4.9$ billion ( $€ 5.5$ billion) raised for biotechnology in Europe's public capital markets.

A veteran of the pharmaceutical and biotechnology sectors, Saxe has exploited his experience to become one of biotechnology's

its profitable phase. From 1989 to 1993, as president and CEO, hesteered toward the market Synergen's lead product, Antril (recombinant interleukin-1 receptor antago-

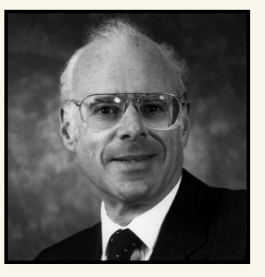

Citation: For multiple and concerted mentoring across the biotechnology spectrum.

Education: BSChE, Carnegie Mellon University, 1957; JD, George Washington University, 1960; LLM, New York University, 1975 Age: 65

Nationality: American

Years in biotech: 13

Current posts: Chairman: Iconix (Mountain View, CA), VistaGen (Burlingame, CA), and Point Biomedical (San Carlos, CA); director:

Questcor Pharmaceuticals (Hayward, CA), Incyte Pharmaceuticals (Palo Alto, CA), Protein Design Laboratories (Fremont, CA), First Horizon Pharmaceuticals (Roswell, GA), ID Biomedical (Vancouver, BC, Canada), Oxon Medica (S. San Francisco, CA), SciClone Pharmaceuticals (San Mateo, CA), Astex Technology (Cambridge, UK), diaDexus (S. San Francisco, CA), InSite Vision (Alameda, CA), and Arbor Vita (Sunnyvale, CA) 


\section{In his own words...}

Self-image: "I have an entrepreneurial risk orientation tempered both by established and startup company experience. I also bring considerable operational and transactional involvement and the perspective of having seen numerous boards interact with a variety of management teams."

Moment of greatest clarity: "There is no one moment I can fix on, but clarity has come rather from a synthesis multiple experiences and feedback from companies and individuals. Change is constant; learning comes from each experience."

Advice to entrepreneurs: "Focus the business plan, and implement the focus."

Advice to government: "Nurture (money does matter), but don't control—support pre-competitive technology."

Most common cause of life science failure: "Undercapitalization."

Worst business habit (self or others): "Staying the course too long and not staying the course long enough; that is, not knowing the right time to terminate projects."

nist; IL-1ra), indicated for rheumatoid arthritis and septic shock. The company established state-of-the-art production facilities and put in place extensive sales machinery for the drug. Unfortunately, Antril- like so many other sepsis drugs- did not get to market at thisstage. Thepromising results of early phase 2 trials were not reproduced in subsequent studies and, by July 1993, the trials for sepsis were stopped and marketing applica- tions withdrawn. Two weeks later, the company had laid off $60 \%$ of its staff and completely restructured its operations.

Saxe had al ready left the company by then, and largely avoided having his reputation tarnished by the events that eventually saw Synergen absorbed, pretty much without a trace, into Amgen (Thousand Oaks, CA) which recently launched Antril as Kineret, for the treatment of rheumatoid arthritis.
Since leaving Synergen, Saxe has put his experiences, both good and bad, to use on behalf of a host of other young companies, initially as a consultant to venture capital firms and their portfolio investments. Hehas also becomeinvolved at board level in a vast array of ventures. Saxeis an "outside-in" kind of entrepreneur, channeling to each of the numerous companies on whose boards hesits a set of personal collected experiences, in particular hisintimate involvement in both sides of pharmaceutical-biotechnology deal making. After serving as a director of humanized antibody company Protein Design Laboratories (PDL; Fremont, CA), he became its president between 1995 and 1999. He retained his directorship at infectious disease outfit Ribogene (H ayward, CA) when it merged with Cypros Pharmaceuticals (Carlsbad, CA) to becomeQuestcor Pharmaceuticals. Saxe believes that the principles of sound business practice know no boundaries in biotechnology. Hencethe companiesheis currently involved with span specialty medicines, genomics, ophthalmic drugs and diagnostics, immunopharmaceuticals, and drug delivery, to namebut a few. 